\title{
Microdistribution within a population of Acrocnida brachiata (Montagu), (Echinodermata: Ophiuroidea) in Little Killary, west coast of Ireland
}

\author{
A. Makra \& B. F. Keegan \\ Department of Zoology, The Martin Ryan Marine Science Institute, \\ The National University of Ireland; Galway, Ireland
}

\begin{abstract}
Acrocnida brachiata (Montagu), like many other infaunal ophiuroids, has a penchant for gregariousness. In Little Killary, a small embayment on the west coast of Ireland, it colonises an extensive tract of sandy inshore ground (ca $7 \mathrm{~m}$ depth), at densities of $150-200$ individuals $/ \mathrm{m}^{2}$. In the course of a two-year study, variation in regular suction-sampling returns prompted a detailed study of the species distribution pattern. Towards this end, 256 contiguous and stratified core samples were taken along a line of transect, in May 1995. These showed randomness with respect to the population at large, but exposed an aggregated distribution for juveniles and adults separately, at different levels within the sediment. Juveniles formed wide, 'loose' patches in the surficial deposit, while aduits formed smaller, denser patches deeper within the sediment. It remains to be seen what this approach may expose, when applied in different seasons, or during different phases of the species life cycle.
\end{abstract}

\section{INTRODUCTION}

Acrocnida brachiata (Montagu) is an infaunal ophiuroid that forms dense aggregations in sandy bottoms. A two-year study of the species population in Little Killary, on the west coast of Ireland, showed a high variation in the sampling returns, which, in turn, prompted a detailed study of its distribution pattern.

Very little is known on the microdistribution pattern of the species. Prior to the present work, the only detailed study was that of Bourgoin (1987), who studied two populations, a subtidal and an intertidal, in Douarnenez Bay, Brittany. Using the Index of Dispersion test for goodness of fit in the Poisson distribution (Elliot, 1971; Krebs, 1989), Bourgoin (1987) concluded that $A$. brachiata is randomly distributed in the subtidal and aggregated in the intertidal.

In the present study, the microdistribution of the species was determined by a contiguous sampling method. This method, which was first proposed by Angel \& Angel (1967), uses the variance to mean ratio, or coefficient of dispersion, to detect non-randomness. This statistic is thought to be a powerful test for non-randomness, even when organisms are only mildly aggregated (Andrew \& Mapstone, 1987). 


\section{MATERIALS AND METHODS}

\section{Sampling site}

Acrocnida brachiata (Montagu) is found in high densities $\left(150-200 \mathrm{ind} . / \mathrm{m}^{2}\right)$ in Little Killary, a small embayment running almost parallel to Killary Harbour, on the west coast of Ireland. The study site is situated ca $25 \mathrm{~m}$ off the shore, where the ophiuroid bed covers a broad, slightly sloping area to a depth of ca $10 \mathrm{~m}$. The sediment is a more or less homogeneous sand, low in organic carbon.

\section{Sampling procedure}

A total of 256 contiguous cores were taken in May 1995. The cores were $5.7 \mathrm{~cm}$ in diameter and $30 \mathrm{~cm}$ in height. One meter of the transect line was sampled per dive, using a grid with 8 modular sections $\left(0.125 \times 0.125 \mathrm{~m}^{2}\right)$ to position the cores. In this way, each sample represented an area of $0.016 \mathrm{~m}^{2}$. The cores were sealed at the top with plastic caps, allowing them to be drawn out of the substrate without loss of material. A length of $32 \mathrm{~m}$ was sampled, giving a total area of $4.096 \mathrm{~m}^{2}$.

After sampling, each core was divided into four vertical sections, $0-2.5 \mathrm{~cm}$ (A), $2.5-5 \mathrm{~cm}(\mathrm{~B}), 5-10 \mathrm{~cm}(\mathrm{C})$ and $10 \mathrm{~cm}$-remainder (D), which were placed in individual, labelled plastic bags and frozen. Later, each section was washed through a $0.5 \mathrm{~mm}$ sieve and sorted under a dissecting microscope (x10). The number of Acrocnida brachiata individuals in each section was counted, and their age and sex were assessed.

\section{Data processing}

When studying distribution patterns, a random distribution is usually the first to be considered. Agreement with a Poisson series is the accepted test for a random distribution (Krebs, 1989). To test for such a conformity, the variance to mean ratio, or coefficient of dispersion, was adopted. To investigate the spatial dispersion of Acrocnida brachiata, results from the 256 cores were variously pooled; numbers in each core were totalled into consecutive block sizes, containing $2^{\mathrm{n}}$ cores, with $\mathrm{n}=0-7$. For each block size, the variance, mean and coefficient of dispersion $I$, were then calculated

$$
I=\frac{\text { Variance }}{\text { Mean }}=\frac{\sum(x-\bar{x})^{2}}{(n-1) \bar{x}}
$$

where: $\mathrm{x}$ = the number of individuals in each block, of each block size

$\overline{\mathrm{x}}=$ the mean number of individuals in each block size

$\mathrm{n}=$ the number of blocks in each block size

with the term 'block size' meaning the number of core samples contained in each block.

The confidence limits denoting deviation from the Poisson expectation (aggregation or evenness) were calculated using the following formula (Angel \& Angel, 1967; Gage \& Coghill, 1977):

$$
1 \pm 2 \sqrt{\frac{2 n}{(n-1)^{2}}}
$$


When the value of the coefficient lies within the limits calculated with the above formula, the distribution is random. When the values lie outside the $95 \%$ confidence limit, the distribution is aggregated, and when they lie outside the $5 \%$ confidence limit, the distribution is even.

The data-set was used in three different ways to elucidate the distribution of different age groups within the sediment:

(a) Full data-set (number of individuals per core)

(b) Data-set divided according to the age of individual Acrocnida:

- number of adults or juveniles per core

(c) Data-set divided according to depth of burrowing:

- number of individuals in each of the four vertical sections.

\section{RESULTS}

Total population (full data-set)

In the 256 cores taken in Little Killary, 229 animals were found. Acrocnida brachiata was randomly distributed at all block sizes (Table 1 ).

Table 1. Coefficient of dispersion and limits of Poisson expectation for the total population of Acrocnida brachiata

\begin{tabular}{|rcccc|}
\hline $\begin{array}{c}\text { No of } \\
\text { blocks }\end{array}$ & $\begin{array}{c}\text { Block } \\
\text { size }\end{array}$ & $\begin{array}{c}\text { Coefficient of } \\
\text { dispersion }\end{array}$ & $5 \%$ & $95 \%$ \\
\hline 256 & 1 & 1.026 & -0.82 & 1.18 \\
128 & 2 & 1.132 & -0.75 & 1.25 \\
64 & 4 & 1.258 & -0.64 & 1.36 \\
32 & 8 & 1.083 & -0.48 & 1.52 \\
16 & 16 & 1.339 & -0.25 & 1.75 \\
8 & 32 & 1.487 & -0.14 & 2.14 \\
4 & 64 & 1.553 & -0.88 & 2.88 \\
2 & 128 & 1.000 & -3.00 & 5.00 \\
\hline
\end{tabular}

\section{Data-set divided according to age}

In the 256 cores, 87 juvenile and 142 adult animals were found. Since each sample represents an area of $0.125 \mathrm{~m}$ in diameter, patch size can be calculated from the number of samples in each block. Accordingly, for juveniles, block sizes 16, 32, 64 and 128 represent areas of $2,4,8$ and $16 \mathrm{~m}$ in diameter, so individuals are randomly distributed within aggregations of these sizes. In the same way, adults are randomly distributed within aggregations of $0.5,1,2$ and $4 \mathrm{~m}$ in diameter, and these are, in turn, randomly distributed within larger aggregations of $16 \mathrm{~m}$ in diameter (Table 2).

\section{Data-set divided according to depth of burrowing}

In the 256 cores, 57 individuals were found at depth level ' $A$ ', 55 in 'B', 104 in ' $C$ ' and 13 in ' $D$ '. At depth level ' $A$ ', animals are randomly distributed within aggregations of 2 , 
Table 2. Coefficient of dispersion and limits of Poisson expectation for adults and juveniles of Acrocnida brachiata

\begin{tabular}{|c|c|c|c|c|c|}
\hline \multirow{2}{*}{$\begin{array}{l}\text { No of } \\
\text { blocks }\end{array}$} & \multirow{2}{*}{$\begin{array}{l}\text { Block } \\
\text { size }\end{array}$} & \multirow{2}{*}{$\begin{array}{c}\text { Coef. of } \\
\text { disper. (ad.) }\end{array}$} & \multirow{2}{*}{$\begin{array}{c}\text { Coef. of } \\
\text { disper. (juv.) }\end{array}$} & \multicolumn{2}{|c|}{ Limits } \\
\hline & & & & $5 \%$ & $95 \%$ \\
\hline 256 & 1 & 0.962 & 1.086 & 0.82 & 1.18 \\
\hline 128 & 2 & 1.081 & 1.150 & 0.75 & 1.25 \\
\hline 64 & 4 & $1.383^{\star}$ & 1.210 & 0.64 & 1.36 \\
\hline 32 & 8 & $1.631^{*}$ & 1.474 & 0.48 & 1.52 \\
\hline 16 & 16 & $2.066^{\circ}$ & $2.056^{\circ}$ & 0.25 & 1.75 \\
\hline 8 & 32 & $2.628^{\circ}$ & $3.528^{\circ}$ & -0.14 & 2.14 \\
\hline 4 & 64 & 2.282 & $8.087^{\circ}$ & -0.88 & 2.88 \\
\hline 2 & 128 & $5.098^{*}$ & $20.512^{\circ}$ & -3.00 & 5.00 \\
\hline
\end{tabular}

4,8 and $16 \mathrm{~m}$ in diameter. This distribution pattern is the same as that found for juveniles, when the data-set is split according to age, and the depth of burrowing is not taken into consideration. This can be explained by the fact that, at this depth level, $93 \%$ of the animals found are juveniles. In ' $\mathrm{B}$ ', animals are randomly distributed within aggregations of 4,8 and $16 \mathrm{~m}$ in diameter.

At depth level ' $\mathrm{C}$ ', animals are randomly distributed within aggregations of $0.5,1,2$, 4,8 and $16 \mathrm{~m}$ in diameter. This pattern resembles the result found for adults (i.e. when the data-set is split according to age), and can be explained by the fact that, at this depth, $95 \%$ of the animals found are adults. Finally, in ' $\mathrm{D}$ ', animals are randomly distributed within aggregations of $0.5,1$ and $2 \mathrm{~m}$ in diameter, which are, in turn, randomly distributed within larger aggregations of $16 \mathrm{~m}$ in diameter (Table 3). The result for depth level ' $D$ ' is not fully reliable, since only 13 animals were returned from the 256 core samples.

Table 3. Coefficient of dispersion and limits of Poisson expectation for individuals of Acrocnida brachiata found in the four burrowing depths

\begin{tabular}{|rccccccc|}
\hline $\begin{array}{c}\text { No of } \\
\text { blocks }\end{array}$ & $\begin{array}{c}\text { Block } \\
\text { size }\end{array}$ & $\begin{array}{c}\text { Coef. of } \\
\text { disp. (A) }\end{array}$ & $\begin{array}{c}\text { Coef. of } \\
\text { disp. (B) }\end{array}$ & $\begin{array}{c}\text { Coef. of } \\
\text { disp. (C) }\end{array}$ & $\begin{array}{c}\text { Coef. of } \\
\text { disp. (D) }\end{array}$ & \multicolumn{2}{c|}{$\begin{array}{c}\text { Limits } \\
5 \%\end{array}$} \\
\hline 256 & 1 & 1.027 & 0.953 & 1.042 & 1.098 & 0.82 & 1.18 \\
128 & 2 & 1.196 & 0.940 & 1.215 & 1.245 & 0.75 & 1.25 \\
64 & 4 & 1.145 & 1.251 & $1.455^{\circ}$ & $1.591^{*}$ & 0.64 & 1.36 \\
32 & 8 & 1.403 & 1.210 & $1.687^{*}$ & $1.884^{*}$ & 0.48 & 1.52 \\
16 & 16 & $2.132^{*}$ & $1.550^{*}$ & $2.195^{*}$ & $1.840^{*}$ & 0.25 & 1.75 \\
8 & 32 & $3.787^{*}$ & $2.678^{*}$ & $3.121^{*}$ & 1.923 & -0.14 & 2.14 \\
4 & 64 & $8.158^{*}$ & $5.351^{*}$ & $3.872^{*}$ & 2.538 & -0.88 & 2.88 \\
2 & 128 & $24.016^{*}$ & $8.018^{*}$ & $11.115^{\circ}$ & $6.231^{*}$ & -3.00 & 5.00 \\
& & & & & & & \\
\hline
\end{tabular}




\section{Vertical distribution}

In Little Killary, Acrocnida brachiata is found primarily at depths between 5 and $10 \mathrm{~cm}$ into the sediment (Table 4 and Fig. 1). $Y^{0}$ juveniles reside mostly in the top $2.5 \mathrm{~cm}$ of the deposit. Overall, juveniles are mainly distributed in the top $5 \mathrm{~cm}$ (depth levels ' $\mathrm{A}$ ' and ' $\mathrm{B}$ '), with $61 \%$ being found in the upper $2.5 \mathrm{~cm}$. Although some adults are found above $5 \mathrm{~cm}, 79 \%$ occur below this depth, and are usually found between 5 and $10 \mathrm{~cm}$ $(70 \%)$, with only a few animals found below $10 \mathrm{~cm}$.

Table 4. The vertical distribution of different age groups in Acrocnida brachiata

\begin{tabular}{lcccc|}
\hline Age & A & B & $C$ & D \\
group & $(0-2.5 \mathrm{~cm})$ & $(2.5-5 \mathrm{~cm})$ & $(5-10 \mathrm{~cm})$ & $(10 \mathrm{~cm}$-rem.) \\
\hline Y) juveniles & 24 & 2 & 0 & 0 \\
Juveniles & 29 & 27 & 5 & 0 \\
Adults & 4 & 26 & 99 & 13 \\
\hline Total & 57 & 55 & 104 & 13 \\
\hline
\end{tabular}

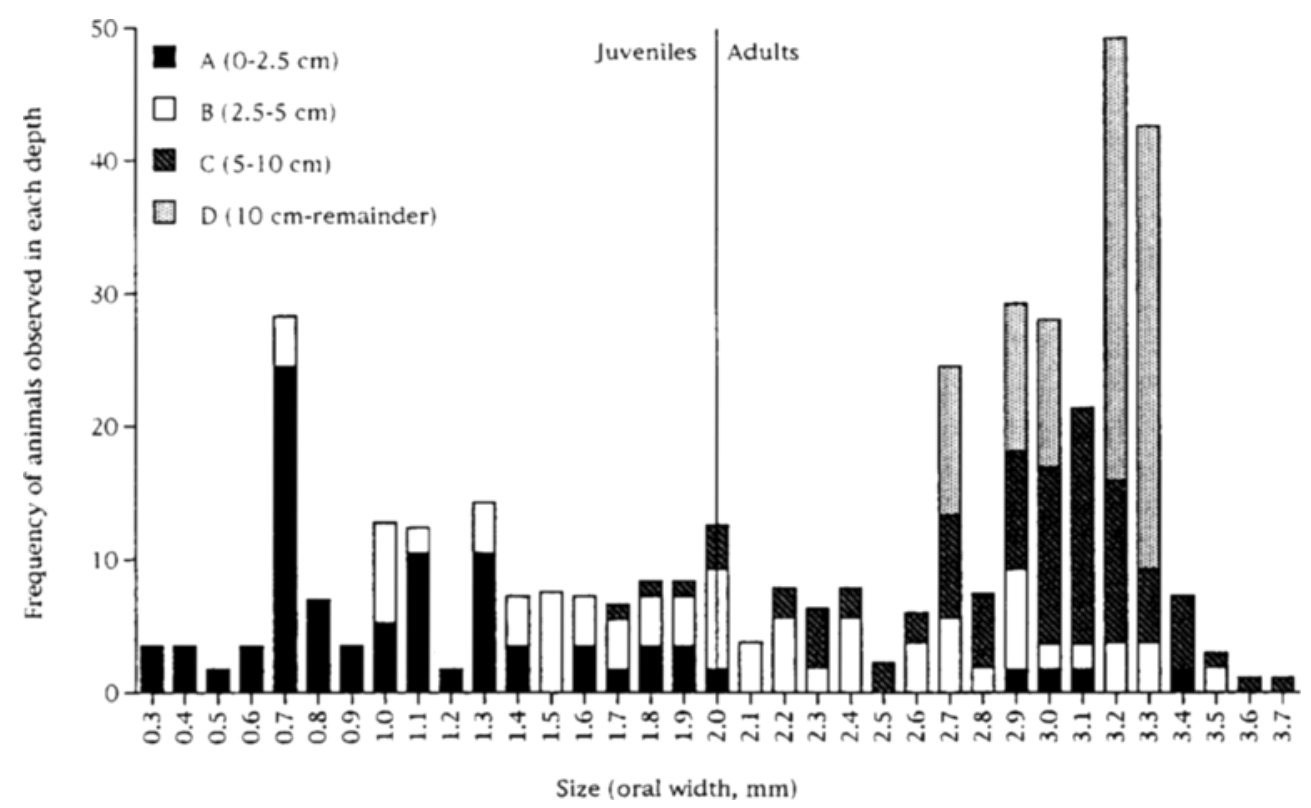

Fig. 1. Frequency histogram for animals found in different depths within the sediment 


\section{DISCUSSION}

\section{Horizontal distribution}

In what are usually accepted as largely homogeneous bottom environments, like that of Little Killary, the dispersion of any species will depend on its behaviour either as an adult, or as a larva, or perhaps both (Wilson, 1976; Thrush, 1991). Aggregation will result only from strong positive interactions (Wilson, 1976), such as may occur during the reproductive season (Heip, 1975), during larval settlement (Crisp, 1961; Wilson, 1968), or perhaps through chance encounters between adults (Keegan et al., 1985). Randomness will prevail only in the absence of interactions between individuals (Wilson, 1976).

Findings for distribution patterns are substantially affected by the size of the sampling unit (Elliot, 1971), and even the size of the mesh used in the sieving process (Rosenberg, 1974). If the sampling unit is much smaller, or much larger, than the actual patch size, aggregation will not be detected (Elliot, 1971). The use of a single sampling unit is not sufficient to determine a distribution pattern, since it is valid only for that sample size (Greig-Smith, 1952). The contiguous sampling method (Angel \& Angel, 1967) used for the present study seems to overcome the problem of sampling unit size, since, by blocking consecutive samples, it gives a progressively wider range of sample sizes (Rosenberg, 1974). Accordingly, it has much to recommend it for studying distribution patterns in benthic invertebrates.

The distribution of the total population of Acrocnida brachiata is found to be random in Little Killary. The same holds for the subtidal population of A. brachiata in Douarnenez Bay (Bourgoin, 1987). As already mentioned, randomness prevails only in the absence of interactions between individuals (Wilson, 1976). If food is abundant, as is usually the case for suspension feeders living in a high energy environment, like Little Killary, and since the population density is relatively low, there should be little intraspecific competition, for food or space. Therefore, one might expect that a suspension feeder, like A. brachiata, would be randomly distributed under such conditions.

On the other hand, Warner (1979) and Keegan et al. (1985) suggest that, in many suspension feeding ophiuroids, aggregation improves their feeding milieu. The extension of arms into the water column, i.e. in dense populations of Amphiura filiformis and, more strikingly, Ophiothrix fragilis, disrupts the bottom current flow, thereby increasing the precipitation of suspended material. However, it should be noted that this "baffle effect" seems to be created only within high density populations, i.e. max. density of ca $2200 / \mathrm{m}^{2}$ for A. filiformis and ca $10000 / \mathrm{m}^{2}$ for O. fragilis (Keegan et al., loc. cit.), while the maximum density ever recorded for Acrocnida brachiata in Little Killary was $300 / \mathrm{m}^{2}$.

Dividing the data set according to age, or depth of burrowing, throws more light on the distribution of different age groups not only in the horizontal, but also in the vertical dimension. Juveniles form wide, 'loose' patches (2-16 m in diameter), at depth level ' $A$ ' $(0-2.5 \mathrm{~cm})$. Crisp (1961) has shown that, although juvenile barnacles are inclined to settle gregariously, they then tend to spread out. This appears to hold for Acrocnida juveniles as well, where a post-settlement spreading out can give rise to the observed 'loose' patches.

Adults form smaller patches (0.5-4 $\mathrm{m}$ in diameter) which, in turn, are randomly distributed in the larger area sampled. These clumps are mainly found between 5 and $10 \mathrm{~cm}$ 
into the sediment, at depth level ' $\mathrm{C}$ '. It is conjectured that this localised clumping of adults may confer advantages related to feeding (Warner, 1979; Keegan et al., 1985), and/or reproduction (Buchanan, 1967; Warner, 1979).

Why does the distribution appear random for the total population, with aggregation only being detected when the population is subdivided according to age or depth of burrowing? Comparing the presence of juveniles in the surficial sediment and of adults at the deeper depth levels, it can be seen that, in any vertical 'profile', where juveniles monopolise the surficial layer, there will be very few adults at the lower depth levels.

As $A$. brachiata is mainly a suspension feeder (Woodley, 1975), and the settling size of juveniles is $0.3 \mathrm{~mm}$ (Webb \& Tyler, 1985), juveniles could be taken as food particles by established adults. For this reason, it is possible that juveniles can settle and survive only where there are very few, or no adults in the sediment below, suggesting here a negative interaction between dense adult patches and settling juveniles (Woodin, 1976; Duineveld et al., 1987).

Vertically separate surficial patches of juveniles, and deeper patches of adults, seemingly cannot overlap. This is not obvious when only the number of individuals per sample is counted, and the age of the animals, or the depth at which they are found, are not taken into consideration. Hence, it is contended that, in Little Killary, A. brachiata forms two distinct and non-overlapping distributions of animals of different ages, found at different depths within the sediment. These two separate dispersion patterns appear to cancel out each other, giving an overall picture of randomness.

\section{Vertical distribution}

Acrocnida brachiata is mainly found between 5 and $10 \mathrm{~cm}$ in the sediment. $\mathrm{Y}^{0}$ juveniles live almost exclusively near the surface $(0-2.5 \mathrm{~cm})$, while juveniles, overall, are found between the surface and $5 \mathrm{~cm}$. Most adults burrow between 5 and $10 \mathrm{~cm}$ into the sediment, and very few specimens, always adults of a large size, are found below $10 \mathrm{~cm}$. A previous study of $A$. brachiata in Little Killary also showed that most individuals were found between 5 and $10 \mathrm{~cm}$ into the sediment (Bowmer, 1978).

The arms of adult $A$. brachiata reach a length of 15 to 25 times the diameter of the disc, which, in adults, translates to a length of 18 to $30 \mathrm{~cm}$. Since $A$. brachiata needs to keep a number of its arms extended into the water column to feed (Woodley, 1975), the depth of burrowing is related to the animals' size (Keegan et al., 1985). Burrowing at a depth between 5 and $10 \mathrm{~cm}$ in the sediment would allow most adult animals to keep at least half the length of their arms extended into the water column. Only large individuals can burrow deeper than $10 \mathrm{~cm}$ and sustain their suspension feeding. Bowmer (1978) also noted that the discs of individuals with all five arms on the surface were never found below $7 \mathrm{~cm}$.

Juveniles are small and fragile (Webb \& Tyler, 1985), with very fine arms, much shorter than in the adults. They are thus confined to the surficial sediment, if they are to engage in suspension feeding. This surficial sediment in Little Killary is of a finergrained nature, and it has a higher water content than the sediment below $5 \mathrm{~cm}$ (Makra, unpubl. obs.). This might result in a more 'loose' substrate, making it mechanically easier for the fragile juveniles to burrow. 


\section{CONCLUSION}

The total population of Acrocnida brachiata in Little Killary displays a random distribution pattern. However, adults and juveniles separately do form aggregations. As the animals grow, they burrow deeper within the sediment. While juveniles form wide, 'loose' patches in the surficial deposit, adults form smaller, denser patches deeper within the sediment. More frequent and extended contiguous sampling is required to investigate these findings further, particularly between different biological seasons, and during spawning and settlement.

Acknowledgements. The authors would like to thank A. Lawless, J. Galvin, T. Craven and D. Burke for technical assistance and for their help in the field. This research was funded by a grant to A.M from the Irish Department of Education (International Section), in collaboration with the Greek Ministry of Education.

\section{LITERATURE CITED}

Andrew, N. L. \& Mapstone, B. D., 1987. Sampling and the description of spatial patterns in marine ecology. - Oceanogr. mar. Biol. 25, 39-90.

Angel, H. H. \& Angel, M. V., 1967. Distribution pattern analysis of a benthic community. - Helgoländer wiss. Meeresunters. 15, 445-454.

Bourgoin, A., 1987. Écologie et démographie d' Acrocnida brachiata (Montagu) (Echinodermata; Ophiuroidea) en Baie de Douarnenez (Bretagne). Diss., Univ. de Bretagne Occidentale, Brest, $146 \mathrm{pp}$.

Bowmer, T., 1978. Aspects of the biology and ecology of Acrocnida brachiata (Montagu) (Ophiuroidea: Echinodermata). B. Sc. Thesis, Natn. Univ, of Ireland, Galway, 95 pp.

Buchanan, J. B., 1967. Dispersion and demography of some infaunal echinoderm populations. Symp. zool. Soc. Lond. 20, 1-11.

Crisp. D. J., 1961. Territorial behaviour in barnacle settlement. - J. exp. Biol. 38, 429-446.

Duineveld, G. C. A., Kunitzer, A. \& Heyman, R. P., 1987. Amphiura filiformis (Ophiuroidea: Echinodermata) in the North Sea. Distribution, present and former abundance and size composition. Neth. J. Sea Res. 21, 317-329.

Elliot, J. M., 1971. Some methods for the statistical analysis of samples of benthic invertebrates. Scient. Publs Freshwat. biol. Ass. 25, 1-144.

Gage, J. D. \& Coghill, G. G., 1977. Studies on the dispersion patterns of Scottish sea loch benthos from contiguous core transects. In: The ecology of marine benthos. Ed. by B. C. Coull. University of South Carolina Press, Columbia, S. C., 319-338.

Greig-Smith, P., 1952. The use of random and contiguous quadrats in the study of the structure of plant communities, - Ann. Bot. 16, 293-316.

Heip, C., 1975. On the significance of aggregation in some benthic marine invertebrates. In: Ninth European Marine Biology Symposium. Ed. by H. Barnes. Aberdeen University Press, Aberdeen, $527-538$.

Keegan, B. F., O' Connor, B. D. S. \& Könnecker, G. F., 1985. Littoral and benthic investigations on the west coast of Ireland - XX. Echinoderm aggregations. - Proc. R. Ir. Acad. 85B, 91-99.

Krebs, C. J., 1989. Ecological methodology. Harper Collins, New York, 654 pp.

Rosenberg, R., 1974. Spatial dispersion of an estuarine benthic faunal community. - J. exp. mar. Biol. Ecol. 15, 69-80.

Thrush, S. F., 1991. Spatial patterns in soft-bottom communities. - Trends Ecol. Evolut. 6, 75-79.

Warner, G. F., 1979. Aggregation in echinoderms. In: Biology and systematics of colonial organisms. Ed. by G. Corwood \& B. R. Rosen. Acad. Press, London, 375-396.

Webb, C. M. \& Tyler, P. A., 1985. Post-larval development of the common north-west European brittle stars Ophiura ophiura, O. albida and Acrocnida brachiata (Echinodermata: Ophiuroidea). - Mar. Biol. 89, 281-292.

Wilson, D. P., 1968. The settlement behaviour of the larvae of Sabellaria alveolata (L). - J. mar. biol. Ass. U. K. $48,387-435$. 
Wilson, J. G., 1976. Dispersion of Tellina tenuis from Kames Bay, Millport, Scotland. - Mar. Biol. 37, 371-376.

Woodin, S. A., 1976. Adult-larval interactions in dense infaunal assemblages: Patterns of abundance. - J. mar. Res. 34, 25-41.

Woodley, J. D., 1975. The behaviour of some amphiurid brittle stars. - J. exp. mar. Biol. Ecol. 18, 29-46. 